\title{
Experiments on the active principle of sarsaparilla
}

\section{Poggiale}

To cite this article: M. Poggiale (1834) Experiments on the active principle of sarsaparilla, Philosophical Magazine Series 3, 5:30, 463-465, DOI: 10.1080/14786443408648509

To link to this article: http://dx.doi.org/10.1080/14786443408648509

册 Published online: 01 Jun 2009.

Submit your article to this journal 준

Џ Article views: 2

Q View related articles $₫$ 
of the sudden Appearance of the Web-spinning Blight of the Apple, Haw thorn, sc." Among those of a more purely scientific character may be mentioned: the Rev. F.W. Hope's Descriptions of some hitherto uncharacterized exotic Coleoptera, chiefly from New Holland; Mr. Waterhouse's Descriptions of the Larvæ and Pupæ of various Species of Beetles ; Mr. Lewis's Descriptions of some new Genera of British Homoptera; Mr. G. R. Gray's Descriptions of several Species of Australian Phasmata, \&c.; whilst others are of a mixed nature, as Mr. Christy's Remarks on a Species of Calandra occurring in the Stones of Tamarinds; Mr. Waterhouse's Account of Raphidia ophiopsis; and Mr. Westwood's Description of the Nest of a gregarious Species of Butterfly from Mexico. The part concludes with the Journal of Proceedings, (a judicious addition, we think, and almost new in the "Transactions" of British societies,) By-Laws, and List of Members. The plates are beautifully executed, each containing a great amount or variety of subjects.

LXVII. Intelligence and Miscellaneous Articles.

DISCOVERY OF SAURIAN BONES IN THE MAGNESIAN CONGLOMERATE NEAR BRISTOL.

A LTHOUGH some of the earliest noticed Saurian remains were $A$ the fossil Monitors of Thuringia, discovered in the Continental equivalents of our magnesian limestone,-characterized by the same testacea and fishes which Mr. Sedgwick has so fully described in our own corresponding formations in the North of England,-it does not appear that Saurian remains have been until now detected in this geological site in our own series. Recently, however, a quarry of the magnesian conglomerate, resting on the highly inclined strata of carboniferous limestone, at Durdham Down, near Bristol, has afforded some Saurian vertebræ, ribs, femora, and phalanges, together with claws, the latter of considerable proportional size : a coracoid bone has also been found, approaching very nearly to that of the Megalosaurus. The general character of the bones seems intermediate between those of this genus and the crocodile. Dr. Riley, who submitted the specimens bitherto discovered, to the Literary and Philosophical Society of the Bristol Institution, is understood to be preparing a detailed account of this interesting discovery for the Geological Society.

The only Saurian remain hitherto found in this island in a site approaching to this, was a fragment of a lower jaw apparently of a Gavial discovered in the lower beds of the new red sandstone at Guy's Cliff, Warwickshire. This fact was communicated by $\mathrm{Mr}$. Conybeare to Mr. Parkinson, and is noticed in the abridged work of the latter on Organic Remains.

EXPERIMENTS ON THE ACTIVE PRINCIPLE OF SARSAPARILLA,

BY M. POGgIALE.

M. Palotta, in 1824, announced an active principle in sarsaparilla which he called parilline. Soon afterwards M. Folchi thought he had discovered a new principle which he named smilacine. In the 
year $1831, M$. Thubeuf stated that he had extracted a new substance from sarsaparilla to which he gave the name of salseparine, and lastly, M. Batka, a German chemist, towards the end of the year 1833, described an acid which he called parillinic acid. The question to be resolved is, are these four substances four new bodies, or are they merely one and the same principle obtained by different methods?

A considerable quantity of parilline, smilacine, salseparine, and parillinic acid was prepared; following the process of M. Palotta, very fine parilline was obtained, but the smilacine of $\mathbf{M}$. Folchi was not so easily prepared; and he was undoubtedly mistaken in saying that an appreciable quantity of smilacine might be obtained by macerating in water one ounce of the pith of sarsaparilla, treating the solution with animal charcoal, and evaporating. It is, according to M. Poggiale, impossible to extract from one ounce of the pith, by means of water, the smallest portion of smilacine; the method adopted by him was to treat the pith with alcohol and charcoal, and the product possessed all the properties of parilline. Although M. Thubeuf did not publish his mode of preparing salseparine, the process was known to be that of making an alcoholic solution of sarsaparilla, treating this with animal charcoal and crystallizing it : the substance obtained possessed no properties differing from those of parilline, as will presently be proved. Parillinic acid was also prepared according to the directions of M. Batka.

These four substances are all white, inodorous, and when deprived of water, without taste. They are very bitter and nauseous to the taste when dissolved in water or alcohol. They are heavier than water; insoluble in cold, but slightly soluble in boiling, water; very soluble in boiling alcohol, less so in cold; boiling æother dissolves them all; the volatile oils take them up perfectly; they are less soluble in the fixed oils; they exert but slight action on turmeric paper, none on litmus, and turn the syrup of violets green. They are all decomposed in the same manner by heat, leaving an extremely light charcoal possessing a metallic lustre. They all crystallize in radiated acicular crystals when an alcoholic solution is carefully evaporated.

The substance obtained by M. Batka is not an acid; it is true it reddens litmus paper, but this property is owing to a small quantity of muriatic acid which it retains : if, however, this supposed acid is washed seven or eight times with water, it will no longer exert any action on the litmus paper. M. Poggiale attaches the greatest importance to the analyses of these substances, which he states he has performed with the greatest care.

Analysis of Salseparine.

Salseparine, dried at $24.8^{\circ} \mathrm{Fahr}$, in a stove and analysed by $\mathbf{M}$. Liébig's apparatus, gave the following results.

\begin{tabular}{lrrr} 
& 1 st. & 2 nd. & 3rd. \\
Carbon & 62.53 & 62.39 & 62.70 \\
Hydrogen & 8.80 & 8.59 & 8.28 \\
Oxygen & 28.67 & 26.02 & 29.02 \\
\cline { 2 - 4 } & $100^{\circ}$ & -97. & 100.
\end{tabular}


Intelligence and Miscellaneous Articles.

The Analysis of Parilline by the same apparatus gives

\begin{tabular}{lrrr} 
& 1 st. & 2nd. & $3 \mathrm{rd}$. \\
Carbon & 62.22 & 62.99 & 62.07 \\
Hydrogen & 8.96 & 8.76 & 8.40 \\
Oxygen & 28.82 & 28.25 & 29.53 \\
\cline { 2 - 4 } & 100. & $100 \cdot$ & 100.
\end{tabular}

Analysis of Parillinic Acid.

\begin{tabular}{|c|c|c|c|}
\hline $\begin{array}{l}\text { Carbon } \\
\text { Hydrogen } \\
\text { Oxygen }\end{array}$ & $\begin{array}{r}\text { 1st. } \\
62 \cdot 98 \\
8 \cdot 88 \\
28 \cdot 14\end{array}$ & $\begin{array}{r}\text { 2nd. } \\
62 \cdot 38 \\
8.96 \\
28 \cdot 66\end{array}$ & $\begin{array}{r}3 \mathrm{rd} . \\
62 \cdot 76 \\
8 \cdot 63 \\
28.61\end{array}$ \\
\hline Oxygen & 100 & $100^{\circ}$ & 100 \\
\hline $\begin{array}{l}\text { Carbon } \\
\text { Hydrogen } \\
\text { Oxygen }\end{array}$ & $\begin{array}{r}\text { Anal. } \\
\text { Ist. } \\
62 \cdot 83 \\
8 \cdot 41 \\
28 \cdot 76\end{array}$ & $\begin{array}{r}\text { Smilacin } \\
\text { 2nd. } \\
62 \cdot 43 \\
8 \cdot 68 \\
28 \cdot 89\end{array}$ & $\begin{array}{r}3 \mathrm{rd} . \\
62 \cdot 08 \\
8.78 \\
2 j \cdot 14\end{array}$ \\
\hline & 100 & 100 & 100 \\
\hline
\end{tabular}

Which experiments denote the atom of salseparine to consist of carbon 8 atoms, hydrogen 15 atoms, and oxygen 3 atoms. From these facts M. Poggiale arrives at the following conclusions: That M. Palotta discovered the active principle of sarsaparilla; that smilacine, parillinic acid, and salseparine are identical with the parilline of M. Palotta, but procured by different methods; that the properties of these four substances are the same; and that the pith of sarsaparilla as well as the bark contains salseparine.-Journal de Pharmacie, October 1834.

PREPARATION OF CYANURET OF POTASSIUM.

According to M. Robiquet, when ferrocyanuret of potassium is calcined in a retort, there are formed cyanuret of potassium and quadricarburet of iron ; and when the retort is carefully broken, a certain quantity of perfectly pure fused cyanuret of potassium is obtained, which is quite fit for medicinal use. - Ibid. Sept. 1834.

\section{COMPOSITION OF LITHIC ACID.}

M. Liebig observes that lithic acid is unquestionably one of the most remarkable organic acids, both with respect to its composition and the effects which it produces in certain diseases, such as gravel, urinary calculi, and gouty concretions.

The composition of this acid has been variously stated, and no two analyses agree: these differences arise from the circumstance of chemists not baving directly determined the proportion of carbon which the acid contains, and are consequently deprived of the controul in determining the azote which M. Liebig conceives that his apparatus admits of.

Third Series. Vol. 5. No. 30. Dec. 1834. 30 